\title{
Political Economy: Success or Failure?
}

\author{
Bruno S. Frey ${ }^{1}$ and Lasse Steiner ${ }^{2}$
}

ABSTRACT

\begin{abstract}
The Political Economy and Public Choice approaches have promoted the study of interactions between the economy and the polity for over 60 years now. The present paper endeavours to provide a critical discussion of this literature and its achievements. In particular, it begins with the different approaches based on empirically tested or politometric models and it then proceeds to discuss different studies of the effects that particular rules of the game have on politico-economic outcomes. The third section of the paper will address studies that take institutions to be endogenous and aims to explain why particular institutions emerge. Finally, the question of whether Political Economy has been a success or a failure will be tackled. While the success in terms of the position it has gained in economic research and teaching is undeniable, a look at one of the most thriving recent areas of economics, happiness research, will reveal that some of its fundamental lessons are all too often disregarded.
\end{abstract}

KEY WORDS: $\quad$ political economy, public choice, constitutional economics, institutions,

JEL Classification: $\quad$ H10, B25, A11

\footnotetext{
1 University of Warwick, UK; CREMA - Center for Research in Economics, Management and the Arts, Switzerland

${ }^{2}$ University of Zurich, Switzerland
}

\section{Politico-Economic Interactions}

Economic activity is influenced by political decisions, and political decisions are influenced by the state of the economy. The interaction of these factors, which is captured by the evaluation and policy functions shown in Figure 1, is so obvious that few people would deny it.

The relationship between these two sectors of society can be illustrated in a more detailed way, as shown in Figure 2:

- The government systematically impacts economic activity via a large number of policy instruments, ranging from taxes and public expenditures to all sorts of regulations. This is the policy function;

- Economic activity, reflected by unemployment and inflation rates as well as size of and changes

Corespondence concerning to this article should be addressed to: bruno.frey@econ.uzh.ch in GNP, determines government popularity and hence the probability of re-election. This is the popularity function.

Political Economy and Public Choice approaches have been used to study these interactions for over 60 years (for general surveys on Political Economy, see the fundamental work by Mueller 1979,1989, 2003). It is the purpose of this paper to provide a critical discussion of the literature exploring these topics, which are often referred to as "politometrics".

There are many other aspects of Political Economy that are not treated here. Examples include the following (see Ostrom, 2012):

- Incentive problems connected with public goods. Olson (1965) argued that individuals have no incentive to contribute to such goods because they can consume them even if they do not help to provide them. Exceptions arise when the number of individuals concerned is small, so that they can exert pressure on each other to participate, or when there are re- 


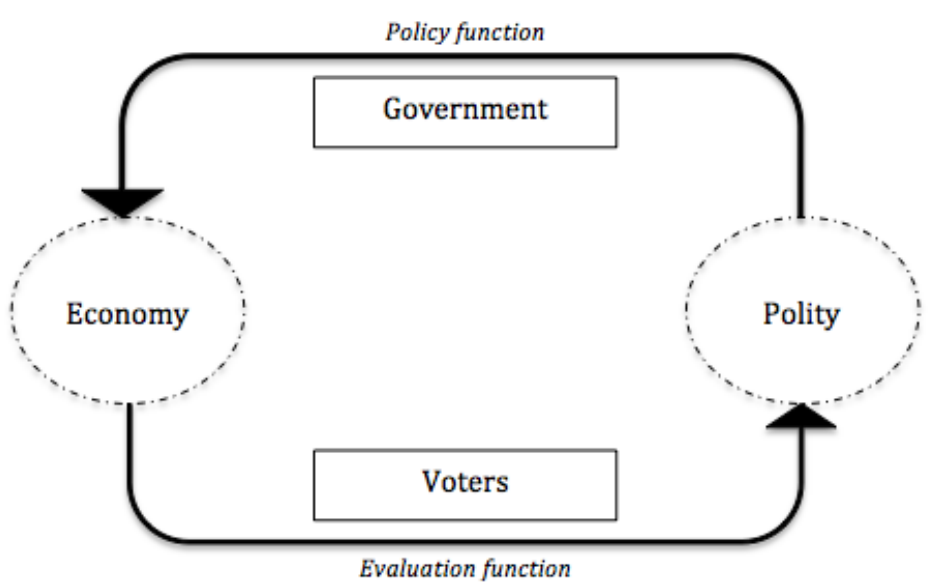

Figure 1. The interaction between the economy and the polity.

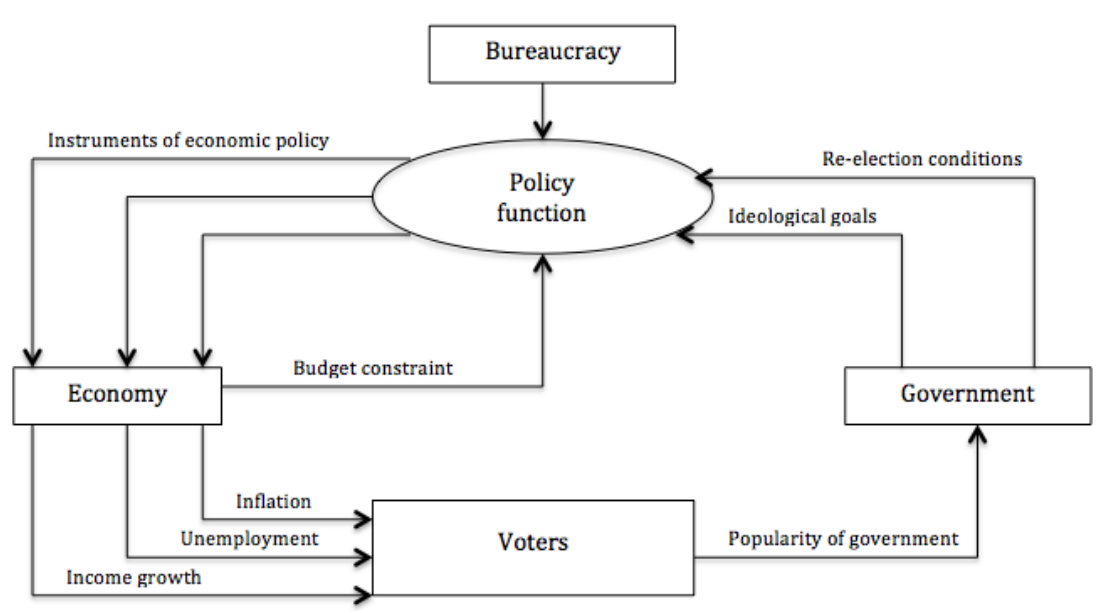

Figure 2. Politico-Economic Model

peated open-ended interactions that may, under favorable conditions, induce individuals to contribute. Most importantly, the government may force individuals to participate by imposing taxes. The fundamental public good problem was later applied to resources and named the "tragedy of the commons" (Hardin 1968, Ostrom, Gardner and Walker 1994). Since then, the conditions under which the supply of public goods is likely to arise has been studied intensively, most importantly by Ostrom (1990), who collected a large data set referring to many different situations involving public goods.

- New Institutional Economics, which originated in Coase's (1937) question of why firms exist. Other important contributions are North (1981), who analysed the structure of institutions and how they change over time, and Williamson (1975), who explored transaction costs as determinants of organisations.

- The structure and performance of local public economies and polycentric systems, such as self-governance. 
In this context, a new form of governance built on a web of multiple intersecting jurisdictions, namely Functional, Overlapping and Competing Jurisdictions (FOCJ, Frey \& Eichenberger 1999), has been suggested.

Part I of this paper addresses the various approaches to Political Economy that are based on empirically tested or politometric models. We will discuss to what extent standard economics takes the mutual interaction of the economy and the polity into account. We will then turn to models that explicitly capture this interdependence, the "politico-economic models". These approaches take the institutional setting of society as given and study how various actors behave within these restrictions.

Part II looks at the institutional setting. It is taken to be exogenous; the effect of particular rules of the game on politico-economic outcomes will be studied here.

The next section (part III) considers institutions to be endogenous. The corresponding studies seek to explain why particular institutions emerge. It discusses recent empirical models that explicitly analyse how the political and economic institutions of a society are shaped by fundamental (exogenous) forces and past events.

Based on this overview, the final part of the paper inquires whether Political Economy has been a success or a failure. It has certainly been a success in terms of the attention it has received and the position it has gained in economic research and teaching. At the same time, the conclusion is also somewhat pessimistic. In many instances in which the politico-economic interaction is crucial, a significant number of scholars still construct models based on the assumption that governments want, and are actually able, to maximise social welfare. Happiness research, one of the most thriving recent areas of economics, will be considered as an important case in point. Leading happiness research scholars wish to charge governments with the task of pursuing, and maximising, the aggregate happiness of the population as an expression of social welfare. In this context, the fundamental lessons and insights of Political Economy are still being disregarded.

\section{Politometrics}

The interdependence of economy and polity seems to be so obvious that one might think that this interaction is fully accounted for in economic research. However, this is not the case in standard economics.

\section{Standard Economics}

We can distinguish various stages in how economists have dealt with this issue:

- Currently, the economy is rarely treated as a closed system, though scholars fascinated by the ArrowDebreu (1954) general equilibrium model still focus solely on economic activity and thus disregard the public sector. The more recent versions of computable general equilibrium models generally include the public sector but model it simplistically.

- Some economic models treat the public sector as exogenous. They study, for instance, how changes in public expenditures, taxes or regulations affect the economy. This is, of course, a perfectly legitimate view. And yet, it remains too narrow because it ignores that the public sector reacts to economic activity.

- Most importantly, an approach that has a long history in economics and remains popular today is to start from the assumption that governments intend to maximise social welfare. This was the expressed goal of the "quantitative theory of economic policy" that was championed by Tinbergen (1956) and Theil (1964) and is still popular today. For instance, the recent concept of "libertarian paternalism" (Thaler \& Sunstein 2003, 2008), based on a behavioural view of human action, particularly decision-making, implicitly assumes that governments would be satisfied by simply "nudging" people in directions that would increase social welfare. However, it may well be that governments attempt to nudge people in a direction that is beneficial to the politicians in power but harmful for society as a whole.

The above approach assumes that governments maximise social welfare. This assumption can be defended by arguing that the resulting socially optimal policy indicates the direction public policy should go in. However, this view has to contend with the fundamental theoretical problem that no social welfare function exists if some rather narrow conditions (such as single peakedness; see Black 1948) are not fulfilled. These conditions are certainly violated as soon as distributional aspects are involved, which is nearly always the case in real life policy decisions. As a consequence, the social 

seems to stem from the fact that it leads to a well-defined equilibrium, which allows researchers to derive clear predictions.

Notwithstanding this criticism, the median voter model may be used to analyse referenda or initiatives in which there are exactly two possible outcomes: acceptance or rejection (see e.g., Pommerehne \& Frey 1976, Romer \& Rosenthal 1978, 1979, 1982). However, few countries in the world use this type of direct democratic decision procedure, with Switzerland being the great exception (see Pommerehne 1978). Therefore, the respective empirical research is useful only in indicating what would be in the interest of those citizens who care to participate in such referenda (in Switzerland, the long run average voter participation rate in referenda is approximately $45 \%)$. It does not necessarily indicate which policies the citizens, and the population as a whole, desire to see implemented.

While the median voter model is certainly elegant and produces an equilibrium outcome as well as allowing for the testing of empirical implications, its assumptions about the political sector, with respect to both political parties and citizens, are extremely narrow and thus rarely fulfilled in reality.

\section{Political Business Cycles}

The interaction between the economy and the polity has been analysed in various quantitative and empirical ways. The government is assumed to maximise votes at exogenously determined election dates, subject to the constraints imposed by the state of the economy. Assuming that the probability of re-election depends on unemployment and inflation rates and letting the economy be represented by an extended Phillips-curve results in a political business cycle (Nordhaus 1975). After an election, the government undertakes a restrictive policy, raising the rate of unemployment but reducing future inflation expectations. In the run-up to an election, the government undertakes an expansionary policy, reducing the rate of unemployment while still profiting from a low inflation rate. This politicoeconomic cycle repeats itself infinitely, i.e. there is no learning on the part of voters or politicians.

A number of scholars have used similar models, and some have discovered different types of political business cycles. An empirical study finds that, contrary to the predictions of Nordhaus' model, left-wing governments tend to undertake expansionary policies after winning elections and, over the election term, move to more restrictive policies (Paldam, 1979).

A broader approach uses an econometric model in which the economy is a constraint to government. Political agents are analysed according to the economic model of human behaviour. Politicians maximise their own utility, which consists of ideological goals as well as pleasure derived from being in power, extracted rents and recognition from voters. They are constrained by the need to be re-elected, so only governments that are confident they will be re-elected according to the popularity function can pursue a purely ideological policy. Left-wing parties tend to increase taxes and public spending, while right-wing parties tend to decrease them. If the popularity function of the incumbent indicates that re-election is uncertain, then the politicians in power will undertake popularity-increasing economic policies. These models have been empirically tested for various industrial (Frey \& Schneider 1975, 1978a, 1978b, 1979, 1981) and less developed countries (Head 1995, Mendoza 1992a, 1992b, Praschnik 1991; for surveys see Frey 1983, Frey \& Schneider 1988). Unlike the models derived by Nordhaus and his followers, these models do not produce pre-determined and identical political business cycles. Instead, the shape of these politicoeconomic cycles depends on a number of determinants, including economic conditions and the nature of political competition. Political competition, in turn, is determined by the number of parties competing and their respective shares of the vote, as well as by the coalitions that are most likely to be formed.

In the literature based on Nordhaus' model, voters are assumed to be myopic. However, the notion that voters are so extremely myopic that they never learn from their mistakes is difficult to reconcile with the assumption that they are actors with rational expectations, which Public Choice is critically based on. Rational expectations were first introduced in the partisan-politics model by Minford and Peel (1982) but the paper by Alesina and Rosenthal (1995) received the most attention. When voters are rational and forwardlooking there is no Political Business Cycle, in stark contrast to the regularly occurring Nordhaus cycle. The cycle reappears only when voters are assumed to be uncertain about the timing of elections, as is the case 

such as the influence of government bureaucracy or interest groups. Such an approach disregards the basic interaction or game played by actors pursuing their own utility. In principle, economic advisers cannot influence the resulting interactions from the outside because each actor is behaving in a way that conforms to his own interests. If this holds, the outcome of the interaction can only be influenced by changes in the rules of the game, or in the constitution shaping these interactions. Thus, effective economic policy advice has to focus on political and economic institutions (see also North 1981, 1990, 2005). Behind the veil of ignorance, economists should offer advice about which institutions lead to outcomes that reflect individual preferences.

The importance of institutional or constitutional rules in determining the outcome of a politico-economic interaction seems to be obvious. Nevertheless, economic analyses tend to disregard not only the current stage with given institutions, as discussed above, but also the constitutional stage.

Most modern textbooks on economics discuss the workings of the economy only within a given institutional setting. This was the case in Keynesian economics and it still tarnishes far more recent versions of economic theory. A perfectly competitive market is often assumed to exist and the effects of policies are simply derived from this particular institutional form. Comparative institutional analysis of different rules of the game, e.g. of a competitive market, a market with strong bureaucratic interventions and an economy without well-defined property rights, tend to be disregarded, especially in macroeconomics. The issues associated with this neglect become particularly obvious in the political sphere. To take an extreme example, consider offering economic advice to an authoritarian ruler. This would have very different implications than to do so for a democratically elected government. There is little point in advising the former to undertake a policy designed to further the "common good", as the ruler's interests are quite different. Instead, the interests of the groups upon whose support the ruler relies, often the military, are the ones that count.

\section{"Political Economics"}

Over the last few years, a new research direction known as Political Economics has emerged. It stud- ies the interaction of political and economic activities by comparing the different outcomes of institutional rules, i.e., it addresses level (2) described above. Interesting extensions of this direction are among others the fields of Law\&Economics or the Economics of Crime (see e.g. Frey, 2011). Usually the approach of Political Economics uses more modern econometric methods than had previously been used but ignores the relevant decades-old Public Choice literature (Mueller 2007). State-of-the-art econometric techniques are used to study the impacts of different constitutional settings on economic outcomes. An important contribution to this literature has been made by Persson and Tabellini (1990, 1999, 2005) who compare the economic consequences of two constitutional choices: (1) majoritarian vs. proportional representation electoral rule and (2) presidential vs. parliamentary form of government.

Persson and Tabellini find that majoritarian electoral rules increase electoral competition, thus resulting in less rent for politicians, less redistribution by the central government, reduced deficits and a smaller central government. Moreover, presidential systems lead to a lower supply of public goods, less rent for politicians, less redistribution and smaller government. They also find that the large electoral districts that are found in proportional representation systems entail more corruption and that parliamentary forms of government are associated with higher productivity. These findings are empirically validated with a large longitudinal data set.

Subsequently, Persson and Tabellini (2005) use a new model to explain the theoretical mismatch they had found with respect to redistribution and proportional elections. The fragmented party system often leads to coalition governments within which there is electoral competition, inducing governing parties to increase spending by the central government. Furthermore, they provide a politico-economic perspective on the nexus between development and democracy by highlighting the importance of sequencing: countries that liberalise their economies before extending political rights fare better.

Clearly, these contributions are noteworthy. What remains questionable is whether this research is, in fact, a new development in the political business cycle literature within Public Choice theory. On a more general note addressed to Persson and Tabellini, Acemo- 

a specialist community of scholars. Their effect on general economics is not very large, but compared to the former self-contained economic theory that completely disregarded politics, much has been achieved.

Meanwhile one can well be disappointed. In particular, the fundamental role of institutions in shaping the behaviour of both political and economic actors is often disregarded. This last statement can be illustrated by policy recommendations emerging from one of the most recent and thriving fields in economics, happiness research. The suggested policy consequences are still guided by a technocratic benevolent dictator approach.

Modern, empirically oriented economic research on happiness was started by Easterlin (1974) and van Praag and Kapteyn (1973). Since then, the major determinants of subjective reported well-being, particularly life satisfaction, have been identified (for surveys see Frey and Stutzer 2002a,b, 2005, Dolan et al. 2008, Frey 2008). Thus, we now know much about how socio-demographic factors (such as age, marital status and personal relationships), economic factors (such as income and its distribution, unemployment, or inflation), cultural factors (such as race or religion), or political factors (extent of democracy and decentralisation) affect happiness. Several prominent happiness researchers (e.g., Diener 2006, Kahnemann 2004, or Layard 2005) suggest that governments should maximise happiness. At last, the dream of economists seems to have come true: the social welfare function has been empirically grounded and thus can and should be maximised.

Politicians have been eager to pick up this new science (Layard 2005) because it promotes the impression that they care for their citizens. The King of Bhutan, the French President, the British Prime Minister, the Chinese President and politicians from several other countries have stated that they wanted to pursue policies maximising or increasing happiness. This sounds like an excellent policy worth supporting; it seems difficult indeed to object to making people happier.

However, more careful consideration reveals that a policy of happiness maximisation is doubtful and perhaps even dangerous in a democratic society. It corresponds to an idea where social welfare can and should be brought about by a government assumed to act solely in the interest of its citizens. This top-down policy, by a technocratic, research-informed and be- nevolent government, stands in sharp contrast to one of the major points of Political Economy: politicians are rational individuals with their own goals and thus act like everybody else: in their own interest. Happiness maximising policies are faced with several other major obstacles (Frey \& Stutzer 2010). Respondents' answers to representative surveys on their happiness level tend to be biased when they are aware that the aggregate happiness index constructed with them will be used for political purposes. Moreover, governments have a strong incentive to manipulate the happiness indicator that is to be maximised. Happiness indicators are based on surveys and create many possibilities to influence the results in favour of the incumbent government.

At the constitutional level (2), the government's claim of pursuing a happiness maximising policy may make it difficult for opposing parties to argue against the party in power, which in turn undermines the intensity of political competition.

Happiness research and the policy proposal that governments should maximise happiness is just one example suggesting that Political Economy has not been sufficiently integrated into economic thinking.

Political Economy has obtained important results but must more actively seek to enlarge the perimeter of its application.

\section{References}

Acemoglu, D. (2005). Constitutions, Politics, and Economics: A Review Essay on Persson and Tabellini's The Economic Effects of Constitutions. Journal of Economic Literature, 43(4), 1025-1048.

Acemoglu, D., Johnson, S., \& Robinson, J. A. (2001). The Colonial Origins of Comparative Development: An Empirical Investigation. American Economic Review, 91(5), 1369-1401.

Acemoglu, D., Johnson, S. \& Robinson, J. A. (2002). Reversal Of Fortune: Geography And Institutions In The Making Of The Modern World Income Distribution. The Quarterly Journal of Economics, 117(4), 1231-1294.

Alesina, A. and Howard R. (1995). Partisan Politics, Divided Government, and the Economy. New York, NY: Cambridge University Press.

Arrow K. J. (1951). Social Choice and Individual Values. New York, NY: Wiley. 
Arrow, K. J. and Debreu, G. (1954). Existence of an equilibrium for a competitive economy. Econometrica, 22(3), 265-290.

Black, D. (1948). On the Rationale of Group Decision-making. Journal of Political Economy, 56(1), 23-34.

Brennan, G. and Buchanan, J. M. (1985). The Reason of Rules. Constitutional Economics. Oxford: Blackwell.

Brunner, A. D. (2003). The Long-Run Effects of Trade on Income and Income Growth, (IMF Working Papers 03/37). Washington, DC: International Monetary Fund.

Buchanan, J. M. (1975). The Limits of Liberty: Between Anarchy and Leviathan. Chicago, IL: University of Chicago Press.

Buchanan, J. M. (1976). A Hobbesian Interpretation of the Rawlsian Difference Principle. Kyklos, 29(1), 5-25.

Buchanan, J. M. and Tullock, G. (1962). The Calculus of Consent: Logical Foundations of Constitutional Democracy. Ann Arbor, MI: University of Michigan Press.

Coase, R. H. (1937). The Nature of the Firm, Economica, 4(16), 386-405.

Diener, E. (2006). Guidelines for National Indicators of Subjective Well-Being and Ill-Being. Applied Research In Quality Of Life, 1(2), 151-157.

Dolan, P., Peasgood, T. and White, M. (2008). Do we really know what makes us happy? A review of the economic literature on the factors associated with subjective well-being. Journal of Economic Psychology, 29(1), 94-122.

Easterlin, R. A. (1974). Does Economic Growth Improve the Human Lot? Some Empirical Evidence, In P. A. David and M. W. Reder (Eds.), Nations and Households in Economic Growth: Essays in Honour of Moses Abramowitz, (pp. 89-125). New York, NY: Academic Press.

Fiorina, M. P. (1977). An Outline for a Model of Party choice. American Journal of Political Science, 21(3), 601-626.

Fiorina, M. P. (1981). Some Problems in Studying the Effects of Resource Allocation in Congressional Elections. American Journal of Political Science, 25(3), 543-567.

Frey, B. S. (1983). Democratic Economic Policy. Oxford: Blackwell.
Frey, B. S. (2008). Happiness: A Revolution in Economics. Cambridge and London: The MIT Press.

Frey, B. S. (2011). Punishment - and Beyond. Contemporary Economics, 5(2), 90-99.

Frey, B. S. and Eichenberger, R. (1999). The New Democratic Federalism for Europe. Functional Overlapping Competing Jurisdictions. Cheltenham, UK and Northampton, MA: Elgar.

Frey, B. S. and Schneider, F. (1975). On the Modelling of Politico-Economic Interdependence. European Journal of Political Research, 3(4), 339-360.

Frey, B. S. and Schneider, F. (1978a). An empirical study of politico-economic interaction in the U.S. Review of Economics and Statistics, 60(2), 174-183.

Frey, B. S. and Schneider, F. (1978b). A politico-economic model of the United Kingdom. The Economic Journal, 88(350), 243-253.

Frey, B. S. and Schneider, F. (1979). An econometric model with an endogenous government sector. Public Choice, 34(1), 29-43.

Frey, B. S. and Schneider, F. (1981). Central Bank Behavior: A Positive Empirical Analysis. Journal of Monetary Economics, 7(3), 291-315.

Frey, B. S. and Schneider, F. (1988). Politico-Economic Models of Macroeconomic Policy: A Review of the Empirical Evidence. In: T. D. Willett (Ed.), Political Business Cycles. The Political Economy of Money, Inflation, and Unemployment, (pp. 240-275). Durham and London: Duke University Press.

Frey, B. S. and Stutzer, A. (2002a). The Economics of Happiness. World Economics, 3(1), 25-41.

Frey, B. S. and Stutzer, A. (2002b). What Can Economists Learn from Happiness Research? Journal of Economic Literature, 40(2), 402 - 435.

Frey, B. S. and Stutzer, A. (2005). Happiness Research: State and Prospects. Review of Social Economy, 63(2), 207-228.

Frey, B. S. and Stutzer, A. (2010). Happiness and Public Choice. Public Choice, 144(3-4), 557-573.

Hardin, G. (1968). The Tragedy of the Commons. Science, 162, 1243-1248.

Head, A. (1995). Country Size, Aggregate Fluctuations, and International Risk Sharing. Canadian Journal of Economics, 28 (4b), 1096-1119.

Hibbs, D. A., Jr. (1987). The Political Economy of Industrial Democracies. Cambridge: Harvard University Press. 
Hibbs, D. A., Jr. (1992). Partisan Theory after Fifteen Years. European Journal of Political Economy, 8(3), 361-373.

Hibbs, D. A., Jr. (1994). The Partisan Model of Macroeconomic Cycles: More Theory and Evidence for the United States. Economics and Politics, 6(1), 1-23.

Hibbs, D. A., Jr. (2000). Bread and Peace Voting in U.S. Presidential Elections. Public Choice, 104(1-2), 149-180.

Kahneman, D., Krueger, A. B., Schkade, D. A., Schwarz, N. and Stone, A. A. (2004). Toward National WellBeing Accounts. American Economic Review, 94(2), 429-434.

Layard, R. (2005). Happiness: Lessons form a New Science. New York, NY: Penguin.

Mendoza, E. G. (1992a). The effects of macroeconomic shocks in a basic equilibrium framework. IMF Staff Papers, 39, 855-889.

Mendoza, E. G. (1992b). The Terms of Trade and Economic Fluctuations (IMF Working Papers 92/98). Washington, DC: International Monetary Fund.

Minford, P. and Peel, D. (1982). The political theory of the business cycle. European Economic Review, 17(2), 253-270.

Mueller, D. C. (1979). Public Choice. Cambridge: Cambridge University Press.

Mueller, D. C. (1989). Public Choice II. Cambridge: Cambridge University Press.

Mueller, D. C. (1996). Constitutional Democracy. Oxford: Oxford University Press.

Mueller, D. C. (Ed.) (2001). The Economics of Politics. Cheltenham: E. Elgar.

Mueller, D. C. (2003). Public Choice III. Cambridge: Cambridge University Press.

Mueller, D. (2007). Torsten Persson and Guido Tabellini, The Economic Effects of Constitutions. Constitutional Political Economy, 18(1), 63-68.

Nordhaus, W. D. (1975). The political business cycle. Review of Economic Studies, 42(2), 169-190.

North, D. C. (1981). Structure and Change in Economic History. New York, NY: Norton.

North, D. C. (1990). Institutions, Institutional Change and Economic Performance. Cambridge: Cambridge University Press.

North, D. C. (2005). Understanding the Process of Institutional Change. Princeton, NY: Princeton University Press.
Olson, M. (1965). The Logic of Collective Action: Public Goods and the Theory of Groups. Cambridge: Harvard University Press.

Ostrom, E. (1990). Governing the Commons. The Evolution of Institutions for Collective Action. Cambridge: Cambridge University Press.

Ostrom. E., Gardner, R. and Walker, J. (1994). Rules, Games, and Common Pool Resources. Ann Arbor, MI: University of Michigan Press.

Ostrom, E. (2012). Coevolving Relationships between Political Science and Economics. ZiF-Mitteilungen, 1/2012, 23-35.

Paldam, M. (1979). Is there an Electional Cycle? A comparative study of national accounts. Scandinavian Journal of Economics, 81(2), 323-342.

Persson, T. and Tabellini, G. (1990), Macroeconomic Policy, Credibility and Politics. London: Harwood Academic Publishers.

Persson, T. and Tabellini, G. (1999). The size and scope of government: Comparative politics with rational politicians. European Economic Review, 43(4-6), 699-735.

Persson, T. and Tabellini, G. (2005). The Economic Effects of Constitutions. Cambridge and London: The MIT Press.

Pommerehne, W. W. (1978). Institutional Approaches To Public Expenditure : Empirical Evidence From Swiss Municipalities. Journal of Public Economics, 9(2), 255-280

Pommerehne, W. W. and Frey, B. S. (1976). Two approaches to estimating public expenditures. Public Finance Review, 4(4), 395-407.

Praschnik, J. (1991). The regularities of international business cycle phenomena: Some evidence from developing countries, (unpublished manuscript), FL: University of Florida.

Rawls, J. (1971). The Reason of Rules. Cambridge, MA: Harvard University Press.

Rogoff, K. S. (1990). Equilibrium Political Budget Cycles. American Economic Review, 80(1), 21-36.

Rogoff, K. S. and Sibert, A. (1988). Elections and macroeconomic policy cycles. Review of Economic Studies, 55(1), 1-16.

Romer, T. and Rosenthal, H. (1978). Political resource allocation, controlled agendas, and the status quo. Public Choice, 33(4), 27-43.

Romer, T. and Rosenthal, H. (1979). Bureaucrats versus voters: On the political economy of resource 
allocation by direct democracy. Quarterly Journal of Economics, 93(4), 563-587.

Romer, T. and Rosenthal, H. (1982). Median voters or budget maximizers: Evidence from school expenditure referenda. Economic Inquiry, 20(4), 556-578.

Sen, A. K. (1970). Collective Choice and Social Welfare. San Francisco, CA: Holden-Day.

Tinbergen, J. (1956). Economic Policy: Principles and Design. Amsterdam: North- Holland Publishing Company.

Thaler, R. H. and Sunstein, C. R. (2003). Libertarian paternalism is not an oxymoron. The University of Chicago Law Review, 70(4), 1159-1202.

Thaler, R. H. and Sunstein, C. R. (2008). Nudge: Improving decisions about health, wealth, and happiness. New Haven, CT: Yale University Press.

The Economist. (2011, December 3). Seasteading. Cities on the ocean. The Economist Technology Quarterly, 12-13.

Theil, H. (1964). Optimal decision rules for government and industry. Amsterdam: North-Holland Publishing. Company, Chicago, IL: Rand McNally.

Van Praag, B. M. S. and Kapteyn, A. (1973). Further evidence on the individual welfare function of income: An empirical investigation in The Netherlands. European Economic Review, 4(1), 33-62.

Williamson, O. E. (1975). Markets and hierarchies: Analysis and antitrust implications. New York, NY: Free Press.

\section{Acknowledgments}

We are grateful to Vera Eichenauer and Jana Gallus for their useful comments in preparing this paper. 